DOI: $10.20472 / E F C .2017 .007 .007$

\title{
MARK IAROVYI
}

Bocconi University, Italy

\section{SASSON BAR YOSEF}

Hebrew University, Israel

ITZHAK VENEZIA

Tel Aviv Yaffo Academic College, Israel

\section{IMPLIED MATURITY MISMATCHES AND INVESTOR DISAGREEMENT}

\begin{abstract}
:
Maturity mismatches (MMs) expose banks to interest rate risk and thus add to the uncertainty and ambiguity of their performance. Given the significance of interest rate risk for banking operations, we study to what extent higher MMs and the increased ambiguity concomitant with them contribute to investor disagreement proxied by trading volume in the banks' equity. We overcome infrequency and opacity of accounting disclosures, which obscure their economic usefulness and the accurate measurements of MMs, by resorting to implied MMs, computed as stock return sensitivities to interest rate changes. We find that implied MMs are positively associated with trading volume, and that the role of returns in this relationship is minimal or null.
\end{abstract}

\section{Keywords:}

Asset-liability mismatch, maturity mismatch, trading volume, investor disagreement

JEL Classification: G12, G14, G21 


\section{INTRODUCTION}

In financial theory, trading and return co-move and this co-movement is risk driven. While return is an integral part of any asset pricing model, trading volume is often overlooked (Cochrane 2007). However, the relationship between risk, prices and trading volume is important, because return reflects changes in the expectations of the market as a whole, and is not necessarily associated with trading, while trading reflects changes in the expectations of individual investors, and is not necessarily associated with price changes (Beaver 1968). The relations between individuals' expectations and those of the market may shed light on how the former are integrated into the latter. Following Beaver's (1968) seminal article, trading volume has been explored from the point of view of investor disagreement (e.g., Harris and Raviv 1993, Gervais and Odean 2001, Odean, 1999, Huberman and Regev 2001, DellaVigna and Pollet 2009).

In this paper we explore the extent to which changes in interest risk affect trading volumes, which indicate the dispersion of investors' beliefs. Maturity mismatches (MMs) are of interest since they are a crucial factor in determining the vulnerability of banks' profits to interest rate changes, and since banks are central to the economy. Ideally, MMs could be measured directly from the banks' financial disclosures. But financial reports are subject to managerial discretion, e.g., managers are reluctant to disclose the detailed maturity of the assets and liabilities in their portfolio, which are necessary for the explicit computation of their interest risks (Morgan 2002, Flannery et al. 2004 and Flannery et al. 2013). Even if MMs are disclosed, the reported maturities are often different from the actual ones due to aggregation of reported items, prepayment and extension risks and the existence of items with ambiguous maturities such as saving and demand deposits. This makes maturity evaluation even more challenging (we expand on this issue in the literature review). In view of the opaqueness of accounting data and the low frequency of their release, it becomes evident that the estimation of MMs based on financial reports cannot be precise.

Such flaws in measuring MMs from accounting data led us to infer MMs from the observed bank return sensitivities to interest rate changes. Based on such estimates, we extend the literature by exploring the effects of banks' (implied) MMs on the volume of trading. We find that monthly changes in MMs are positively correlated with increased trading, which, consistent with the extant literature, can serve as proxies to investors' disagreement about stock prices. ${ }^{1}$ We document a positive relationship between implied MMs and stock trading volume on a sample of AMEX, NYSE and NASDAQ listed financial institutions in the post-decimalization era, spanning from January, 2000 to December, $2012 .^{2}$ Our results appear robust to the several classes

\footnotetext{
1 See, e.g., Karpoff 1987, Harris and Raviv 1993, Blume et al.1994, and Kim and Verrecchia 1994.

${ }^{2}$ Among other studies of the effects of several other types of information on disagreement we can find: Kandel and Pearson 1995 (earning announcements), Lo and Wang 2000 (market beta), Dzielinski and Hasseltoft 2014 (news flows) and Ferson and Lin 2014, (Jensen's alpha).
} 
of interest rates and to alternative measures of disagreement. We further show that MMs influence volume beyond their indirect effects on trading, through their possible effects (if such effects are present) on prices.

Our findings shed light on the functioning of capital markets, and may be useful to investors, analysts and regulators. If MMs cause investor disagreement and therefore induce costly trading, then the provision of additional information on MMs is beneficial and actions encouraging the dissemination of pertinent information about MMs that would reduce disagreement should be applauded.

The rest of the paper is organized as follows. In Section 2 we review the literature. Section 3 describes the data. In Section 4 the testable predictions are constructed, and the methodology and estimation procedures are explained. In Section 5 the results are presented and discussed, and Section 6 provides a number of conclusions.

\section{MOTIVATION AND RELATED LITERATURE}

We review the extant literature that directly relates to the issues of investor disagreement stemming from MMs, in three stages: Subsection 2.1 reviews related literature on MMs. In Subsection 2.2 we discuss the issues of the banks' opacity obscuring MM measurements, as well as stress the advantages of using interest rate sensitivities as implied MMs. Subsection 2.3 covers the relevant literature related to disagreement among investors and its correlation with trading volume.

\subsection{MMs and interest rate risk}

The extent of the literature on banks MMs does not match the importance of this topic. Past research investigating MMs mostly concentrates on risk management techniques in response to interest rate risk exposure. Purnanandam (2007) finds that U.S. banks intensify hedging of on-balance sheet exposure with interest rate derivative contracts once their probability of default increases. Ruprecht et al. (2013) model the simultaneous choice of an on-balance duration gap and off-balance interest rate swap use of German banks. They find that higher bankruptcy risk induces banks to reduce $\mathrm{MM}$ and increase the propensity to hedge this gap with interest rate swaps. Landier et al. (2013) study income gaps (the difference between interest rate sensitive loans and deposits). They report that, on average, banks tend to hold positive gaps, and the larger the gaps the more sensitive banks are to interest rate changes, despite the use of derivatives to hedge these risks. Similar conclusions were also reached by English et al. (2012). 


\subsection{Deficiencies of estimating MMs from financial reports and the advantages of implied MMs}

The above studies on MMs and risk suffer from very serious shortcomings, since they measure MMs based on balance sheet information. First, the maturities of many banks' assets and liabilities, such as cash holdings, saving accounts and demand deposits, are ill-defined and researchers do not agree on whether to classify these as long-term or short-term items.

Second, there is a considerable distinction between actual and stated maturity of items on the balance sheet. Data on the actual maturities of items are rarely available to bank outsiders due to non-mandatory disclosure of such information, but banks do take the data into account while building risk hedging strategies. In financial literature, this dissimilarity between actual and stated maturities is known as prepayment or extension risk. As an example of prepayment risk, consider the case where the rate payable on a floating rate loan is expected to increase but the borrower may choose to prepay the entire loan earlier than expected. When such a situation arises, the bank will experience a reduction in interest income. The opposite scenario is known as the extension risk.

Third, instruments with the same repricing dates may respond differently to changes in different interest rates (known as a basis risk). When an asset and a liability otherwise having the same repricing date are tied to different rates (say, Treasury bill and LIBOR), the fluctuation in underlying rates will create exposure of the bank to the spread between the rates. The stated maturities would ignore this nuance and give a researcher misleading information about the quality of balance sheet items.

Fourth, there is a problem of over-aggregation coupled with managerial reporting discretions that is allowed by regulators, such as the Generally Accepted Accounting Principles (GAAP) and bank-specific regulations, together with managerial opportunism. These issues are nicely summarised by Saunders and Cornett (2008, p.203): "defining buckets over a range of maturities ignores information regarding the distribution of assets and liabilities within those buckets... On average, liabilities may be repriced toward the end of the bucket's range, while assets may be repriced toward the beginning, in which case a change in interest rates will have an effect on asset and liability cash flows that will not be accurately measured".

There are further interest rate risks that are not divulged in the banks reports, such as the risk of exposure stemming from extensive usage of complex derivatives (e.g., cross-currency swaps) and off-balance sheet items that are intangible contract obligations.

In light of the inadequacies of accounting data for measuring MMs, we suggest using implied MMs measured as return sensitivities to interest rate changes. We base this 
choice on the pioneering findings of Flannery and James (1984), who documented a strong link between traditionally measured and implied MMs in the cross-section of U.S. traded banks. Extensive research has confirmed the conclusions of Flannery and James (1984) by expanding them to account for several types of interest rates, different time frames and different methodologies (see, e.g., Choi et al. 1992, Song 1994, Chamberlain et al. 1997, and Schrand 1997).

\subsection{Investor disagreement and trading volume}

Beaver's (1968) seminal article paved the way for studying the issue of dispersion in beliefs among shareholders and volume by documenting unusually high trading volume around earning announcement dates. The robustness of Beaver's (1968) finding was further established by a series of studies (e.g., Bamber 1987, Bamber and Cheon 1995, Garfinkel and Sokobin 2006, Garfinkel 2009, D'Agusta et. al. 2014, Kandel and Pearson (1995) documented a significant increase in trading activity around earning announcements even when event returns were close to zero, thus showing that it is disagreement rather than returns that affects the volume. Chae (2005) interpreted the observed patterns in trading before scheduled and unscheduled events from the perspective of strategic planning of informed and uninformed traders who act to minimize adverse selection costs. Carlin et al. (2014) pointed out that disagreement produces risk premium by increasing expected return, but periods of high disagreement are followed by periods of lower trading once investors learn from the observed patterns.

A large body of theoretical work builds upon the divergence of opinions among equityholders and provides diverse motives for investor disagreement. ${ }^{3}$ Harrison and Kreps (1978) suggest a model of speculative trading by heterogeneous investors anticipating time-varying information flow. The importance of noise traders was first established in the seminal paper of Milgrom and Stokey (1982), who showed that no trading will occur in an environment with identical investors in the absence of noise traders. Kyle (1985) posits that information asymmetry increases trading because informed investors attempt to exploit their private information. Foster and Viswanathan (1996) build a model in which differentially informed traders attempt to predict the behaviour of each other, and where trading outcome is determined by the correlation structure of subjective signals.

Some of the literature studies the mechanisms of investor disagreement occurrence. According to the gradual information flow hypothesis, at any one time period traders share different information sets on bank risks, and therefore trading occurs as an outcome of continuous information disclosure to each group of traders (Huberman and Regev 2001). Limited attention theory posits that traders might have equal access to

\footnotetext{
${ }^{3}$ Another strand of literature studies the disagreement between other two groups of stakeholders: investors and managers (see Dittmar and Thakor 2007, Huang and Thakor 2013). Nonetheless, in this paper we choose to concentrate on the more canonical version of disagreement among investors themselves because of its established effect on trading leaving the other type of disagreement for further research.
} 
information and share similar heuristics, and yet trade differently because of information overload and cognitive distractions (DellaVigna and Pollet 2009). Heterogeneous (prior) beliefs may cause disagreement about the significance of events (news), since by Bayes Rule they induce heterogeneous posterior beliefs (Harris and Raviv 1993). If investors are overconfident (but not all at the same level) then they will differ in their assessment of the accuracy of their prior information, and hence, as in the Heterogeneous Beliefs theory, they will differ in their posterior beliefs (Gervais and Odean 2001).

We hypothesise that implied MMs, as surrogates for bank risks, are positively associated with trading volume, and that the role of realized returns in this relationship is minimal or non-existent.

\section{DATA}

For banks' stock market data we use the Center for Research in Security Prices (CRSP)/COMPUSTAT merged database accessible through Wharton Research Data Service (WRDS). We broadly define banks as firms having 60 (depository institutions) or 67 (holding companies and other investment offices) as the first two digits in the Standard Industrial Classification (SIC). This choice expands our dataset beyond commercial banks to also cover, for example, mutual funds and trusts. Since interest rate sensitivity due to MMs is pertinent for these institutions as well as for banks, we opted to include them in the sample. ${ }^{4}$ Accordingly, our data set includes 270,981 bank-month observations.

Risk factors are obtained from several sources. From CRSP we retrieve returns on value-weighted S\&P 500 index and on risk free indices constructed from Treasury bond rates with maturities of 1 and 7 years. From the Federal Reserve Board we obtain 3 month LIBOR, 1 year LIBOR and 7 year swap rates. Our data on LIBOR, interest rate indices, and S\&P 500 Index span the period from January 1999 to December 2013 and on swap rates from August 2000 to December 2013. All interest and market returns are computed as the monthly changes in the corresponding rates.

We retain in the sample only actively traded stock, while excluding stocks whose trading is classified as 'halted' or 'suspended'. We include common shares, certificates, American Depository Receipts (ADRs) and shares of beneficiary interest (SBls), but remove items classified as units because of their limited liquidity and because they may possess option-like characteristics which make their trade different from other securities in the sample. Lastly, in view of the differences between firms listed on global and on regional stock exchanges, we include cross-listed shares but

\footnotetext{
${ }^{4}$ The beginning of our sample, circa 1999, coincides with the Gramm-Leach-Bliley Act, also known as Financial Services Modernization Act of 1999, which repealed the Glass-Stegall Act, thus allowing financial institutions to engage in banking activities.
} 
retain only stock whose primary listing is in one of the major stock exchanges (NYSE, AMEX or NASDAQ). ${ }^{5}$ The end sample contains 45,471 bank-quarter observations.

In our robustness tests we also used dispersion of analysts' forecasts retrieved from I/B/E/S, as an alternative measure of investor disagreement. We collected our data from the section classified as "Banks" in I/B/E/S and for the time period of January, 2000 to December, 2012. The items collected were standard deviation of 12-month forward earnings per share (EPS) forecasts, their means and the number of analysts who made these predictions. Within the above-mentioned sample we kept only U.S. incorporated and AMEX, NYSE and NASDAQ listed banks.

\section{METHODOLOGY}

Our hypotheses are that bank'-implied MMs increase trading volume, and that the role of realized returns in explaining this effect is minimal or even non-existent. To test our hypotheses we first calculate the sensitivity of returns to interest rates in order to construct our implied MMs, and then run regressions to test the extent to which these MMs are correlated with volume.

\subsection{Estimating the implied MMs}

To compute the implied MMs, we use the Fama-French 3 factor model and add to it a sensitivity to interest rate factor, $R_{t}^{I}$. We thus run regressions of the following form for each bank (dropping the bank's subscript i from the equation to reduce clutter):

$$
R_{t}=\alpha_{t}+\beta_{t}^{C A P M}\left(R_{t}^{M}-R_{t}^{f}\right)+\beta_{t}^{I} R_{t}^{I}+\beta_{t}^{H M L} H M L_{t}+\beta_{t}^{S M B} S M B_{t}+\epsilon_{t}
$$

where $R_{t}$ is a total monthly holding period return (capital gain plus dividend yield) on a bank's stock for period t, $\left(R_{t}^{M}-R_{t}^{f}\right)$ is a market risk premium factor, $R_{t}^{I}$ is a monthly change in a given interest rate (we used the following alternative measures of interest rate: Treasury 1 year, Treasury 7 years, LIBOR 3 months, LIBOR 1 year or swap rate 7 years), and SMB and HML are the standard Small-Minus-Big and High-Minus-Low Fama French factors. ${ }^{6}$ The estimates of the $\beta_{t}^{I \prime} s-$ the bank's sensitivities to interest rate returns - serve as our estimates of the implied MMs.

\footnotetext{
${ }^{5}$ Stocks which are not listed on global stock exchanges usually do not comply with their listing requirements and, being listed regionally, are smaller and less liquid. Additionally, dissimilarities in trading psychology and information flows may significantly bias estimates in the second stage. This last exclusion of regionally listed firms, however, is not very restrictive, because once all data clearing is executed only a small portion of stock is primarily listed outside of the major three.

${ }^{6}$ Risk factors could be cross-correlated, but we choose to deal with the potential correlation in the second stage exclusively by controlling for possible sources of covariation. We do not orthogonalize risk factors because this can bias the coefficients (Giliberto 1985). Another alternative to orthogonalization would be to compute principal components of market, interest and exchange returns and plug them into equation (1) as risk factors. We did execute principal component analysis for the returns but, because of evenly high correlations between some
} 
We use rolling windows of 48 months each to compute the sensitivities according to a 'symmetric' algorithm, i.e., for each period (month) we estimate a three-factor model of stock returns on equity, and interest rate using observations over 24 months before it and 24 months after it. We use this method to allow for the possibility that the $\beta_{t}^{I}$ 's change over time. Accordingly, for any period t, starting the month $\mathrm{t}=25$ we estimate the $\beta_{t}^{I}$ using information from both past observations during periods (t-1) to (t-24) and from future observations $(t+1)$ to $(t+24)$, and proceed this way up to the latest sample period. $^{7}$

Our choice of monthly frequency reflects a balance between the pros and cons of this frequency compared to its alternatives. As opposed to more informative weekly and daily data, monthly data are less noisy and contain more economically relevant information. As opposed to quarterly data, monthly data ensure the sufficient number of observations needed to implement a moving beta procedure, even though they do not fit the quarterly accounting reporting frequency.

\subsection{The correlation between implied MMs and volume}

While there is no perfect or unique measure of trading activity, turnover has several benefits over the alternatives (see Lo and Wang 2000 for a detailed discussion). Hence, we use the following metric. For each pair of month and bank we compute the monthly turnover as the sum of its daily turnovers (as in equation 1, we drop the bank subscript). ${ }^{8}$

$$
V=\sum_{s} V_{s}=\sum_{s} \frac{\text { volume }_{s}}{\text { shares }_{s}}
$$

where $\mathrm{V}$ stands for monthly turnover, $\mathrm{V}_{\mathrm{s}}$ stands for total turnover on a particular day $s$, volume $_{s}$ is the total number of the bank's stocks traded on all stock exchanges on day $s$ and shares $_{s}$ is the total amount of common shares outstanding on day $s$. Our

components and some returns, we couldn't find a "good" match between the former and the latter. In the presence of such ambiguous correlations, the interpretation of beta coefficients at principal components would be too perplexing. So, while principal components may successfully resolve multicollinearity, they would introduce another, much more corrupting issue - incomprehensibility of beta estimates.

\footnotetext{
${ }^{7}$ Eliminating current period t's observations from the estimates may help avoid reverse causality in the next stage. Exclusion of the current return from estimating sensitivities may be a sufficient condition for exogeneity of the effective MMs only if there is strong autocorrelation in returns. In our sample, the average first order autocorrelation of returns across panels is already close to $0 \%$, with higher order correlations gradually decreasing. The benefit of this method over using a 'lead' approach implemented on purely historic data is twofold. First, it allows us to eliminate bank-month observations on young banks (first 12 months after IPO or first date when data for a bank are available) that did not have time to form mature portfolios and gain sufficient visibility among investors. Their presence would introduce downward bias in trading volume in the next stage. Second, it allows us to exclude bankmonth observations on banks close to their liquidation date (last 12 months before running bankrupt or being acquired), which may be characterized by abnormal trading due to distress (e.g., coming from extensive fire sales as a result of liquidity issues). Their presence would introduce upward bias in trading volume in the next stage.

${ }^{8}$ The primary advantage of using turnover is that it allows capturing the change in trading volume due to changes in the number of shares outstanding, such as stock splits, share repurchases and seasoned equity offerings.
} 
measure of common shares outstanding is adjusted for ADR conversion ratio for foreign incorporated banks. To deal with positive skewness in turnover, we calculate its natural logarithm. Our primary measure of investor disagreement is thus the industry-adjusted turnover, G, defined by:

$$
G=\log (V)-\log \left(V^{M}\right)
$$

where $\mathrm{V}^{\mathrm{M}}$ is a monthly turnover in the banking industry obtained by summing up the daily turnovers of all the banks in our sample in a given month and $\log ($.$) denotes$ natural logarithm. Throughout the paper we use log-log as our main specification, except for when we note otherwise. This specification is advantageous as it transforms and approximates even highly skewed variables to normal. ${ }^{9}$ In the robustness check, we examine some of the implications of this formulation.

We run generalized least squares (GLS) regressions of the following form to estimate the relationship between our measures of industry-adjusted volume and the implied $\mathrm{MMs}^{10}$ :

$$
\log \left(V_{i t}\right)-\log \left(V_{M t}\right)=\gamma_{0}+\gamma_{1} \log \left|\beta_{i t}^{I}\right|+\tau^{\prime} X+\pi_{i}+u_{i t}
$$

The $\pi_{i}$ are bank fixed effects, the $\left|\beta_{i t}^{I}\right|$ 's are the absolute values of interest rate risk and $X$ denotes a vector of the following covariates:

- $\quad\left|\alpha_{i t}\right|$ is an absolute value of the intercept estimated from Equation (1);

- $\left|\epsilon_{i t}\right|$ is an absolute value of an error term from Equation (1);

- $\quad \log \left(p_{i t}\right)$ is a logarithm of the opening monthly price;

- $\quad \log \left(c_{i t}\right)$ is a logarithm of capitalization computed by multiplying its opening price with the number of total shares outstanding on the first day of the month;

- $\quad \log \left(d_{i t}\right)$ is a dividend-to-price ratio;

- $\sigma_{i t}$ is standard deviation of daily returns;

- $\quad \chi_{i t}(1)$ is first order auto-covariance of daily returns;

- $\quad\left|\beta_{i t}^{\text {CAPM }}\right|$ is an absolute value of CAPM beta from Equation (1);

- $\quad\left|\beta_{i t}^{S M B}\right|$ is an absolute value of SMB beta from Equation (1);

- $\quad\left|\beta_{i t}^{H M L}\right|$ is an absolute value of HML beta from Equation (1);

- $\quad Y E A R$ is a vector of year dummies;

\footnotetext{
${ }^{9}$ We also calculate but do not report vector inflation factors (VIF) for the MMs in the next step. The VIF values range from 2.5 to 3.5, sufficiently low to avoid the critical values recommended by the rule of thumb of " 10 or higher' for defining multicollinearity. . We achieve an increased precision of the coefficients' estimates by using a large sample, which by the central limit theorem drives the variables close to normal.

${ }_{10}$ We use GLS in order to correct for the autocorrelation resulting from using overlapping data. For a robustness check, we also repeated all our tests using Newey-West estimation using lag length 3, 6, 12 and 24. The results obtained under this procedure are qualitatively similar to the ones obtained under the GLS procedure and therefore are not reported here but they can be obtained from the authors upon request.
} 
- MONTH is a vector of month dummies. ${ }^{11}$

In line with our hypothesis, $\gamma_{1}$, the effect of interest rate sensitivity on volume is expected to have a positive sign.

We use bank capitalization as a proxy for visibility (Merton 1987, Dahlquist and Robertsson 2001, Chordia et al. 2007). Larger firms have a more diverse ownership, which leads to more active trading (Merton 1987). Additionally, institutional investors follow the "prudent man laws" by investing more in larger capitalization firms (Badrinath et al.1989, Del Guercio 1996). Size is also positively correlated with a number of analysts following a bank (Chordia et al. 2007), which stands for the larger mass of informed agents (Brennan and Subrahmanyam 1995. Price levels are also related to stock visibility. They are inversely related to brokerage commissions, and so brokers tend to advertise low-priced stock more actively in an attempt to increase brokerage revenues (Brennan and Hughes 1991, Angel 1997, Schultz 2000).

The inclusion of alpha in our model is motivated by its link to the expected return from CAPM and APT models. It may also contain a liquidity premium as documented by a number of previous studies (see Amihud and Mendelson 1986a, 1986b; Hu 1997. It also captures the extent of heterogeneous information about the stock (Wang 1994, He and Wang 1995, Ferson and Lin 2010). Similarly, absolute values of errors are included in the equation to control for the possibility that unobservable effects (for example losses from liquidity drains or fluctuation in other market risks such as oil prices) might have consequences for trading.

We include market beta in the controls of Equation (4) since in addition to measuring systematic risk it also proxies estimation uncertainty about fundamental value of a stock, thus potentially affecting trading volume (Coles and Loewenstein 1988, Coles et al. 1995). Absolute values of HML and SMB betas are included as controls since they may reflect a particular composition of the bank's balance sheets and risk structures. Dividend yield is positively related to abnormal returns in the extant empirical literature. According to the so-called dividend-capture trades, stock is acquired just before the ex-dividend date and then sold shortly after it. ${ }^{12}$

Standard deviation of daily returns is used as a proxy for uncertainty about fundamental values (see Karpoff 1987, Gallant et al. 1992, Zhao and Wang 2003, Yin 2010). In particular, in periods of high uncertainty stock could be more frequently traded because of upward and downward trajectory reversals in the price movements (Karpoff 1987). High volatility may also lead to higher rebalancing needs, and thus to higher turnover (Lo and Wang 2000). On the other hand, high and negative daily stock

\footnotetext{
${ }^{11}$ Equation (4) represents a 'full' model. To preclude the possibility of simultaneity and reverse causality in the presence of some of the above listed controls, we also try a 'restricted' model which excludes some potentially endogenous controls (alpha, errors, volatility and autocovariance) from Equation (4). The results of such an examination will be highlighted later on.

12 See Lakonishok and Smidt (1986), Lakonishok and Vermaelen (1986), Karpoff and Walkling (1988, 1990), Michaely (1991), Stickel (1991), Michaely and Murgia (1995), Michaely and Vila (1995, 1996), and Lynch-Koski (1996).
} 
return autocovariance is synonymous to larger effective bid-ask spread (Roll 1984). ${ }^{13}$ Consequently, we expect it to have a positive effect on turnover. We control for possible seasonality in turnover by using month and year dummy variables. Finally, bank effects are used to capture the 'normal' level of trading in the bank's stock.

\section{RESULTS AND DISCUSSION}

\subsection{Descriptive statistics}

Panel A of Table 1 presents the descriptive statistics of all returns used to estimate the coefficients of Equation (1). Note that, among all non-equity returns, 1-year Treasury bond return has the lowest volatility, and 3-month LIBOR return exhibits the highest volatility. At the same time, 3-month LIBOR produced the largest $(47.14 \%)$ and the smallest returns $(-43.85 \%)$ in the sample. Also note that all returns are clustered around zero, indicating that investments in financial instruments did not produce risk premiums over the sample horizon.

Panel B of Table 1 presents the correlation matrix of the return variables on the RHS of Equation (1). One notes that for both the Spearman and the Pearson correlations of market returns are highly negatively correlated with Treasuries returns, but highly positively with 7-year swap returns.

Table 2 presents summary statistics of all the non-return variables on the RHS of equation (1). The table reveals that the variables values are similar to those reported in prior studies. The average capitalization of the banks in the sample is $\$ 1.88$ billion, with standard deviation of $\$ 10.4$ billion. The average number of shares outstanding is $\$ 82.33$ million, whereas the mean turnover is 0.06 . Additionally, note that the prices' and dividends' distributions are highly positively skewed (5.95 and 2.52, respectively). Our sample is comprised of securities with share prices ranging from the low of $\$ 0.1$ to $\$ 504.7$, with a mean of $\$ 17.1$. The total annual cash dividend paid varies from $\$ 0$ to $\$ 10$ per share, with a mean of $\$ 0.8$.

\subsection{Estimating MMs (first stage estimation)}

Table 3 presents the distributions' parameters of the rolling windows' coefficients from Equations (1). Note that the distributions' means of the interest rate betas are clustered around zero with approximately symmetric tails, meaning that banks do not play the role of maturity transformers (e.g., issuers of long-term loans and attractors of short-term deposits). The table also indicates that interest rates represent no price factors, as opposed to CAPM beta, HML beta and SMB beta, which are all positive.

\footnotetext{
${ }^{13}$ The positive values of autocovariance are associated with negative effective bid-ask spread. Instead of setting positive values to zero or even dropping them, as some authors do in an attempt to derive Roll measure, we follow Lo and Wang (2000) and keep its actual values in all our regressions.
} 
One may also observe that the average of the interest beta estimates of the 1-year Treasury rate (1.993) is larger than that of the 7-year rate (0.193), as well as more dispersed. This feature is consistent with previous studies showing that shorter maturity Treasury rates have a higher absolute value effect on stock prices and embody larger variation (e.g., Flannery and James 1984, Choi et al. 1992, Song 1994). ${ }^{14}$

Table 4 presents a correlation matrix of the actual beta estimates from Equation (1). The lower triangle exhibits Pearson correlations and the upper triangle exhibits Spearman rank correlations. To start with, interest betas estimated on treasuries with maturities of 1 year and 7 years have the highest correlations in the sample. Their Spearman rank correlation is $73.03 \%$ and their Pearson correlation is $60.67 \%$. Correlations among other interest betas are lower and sometimes even negative. The peculiar thing is that the interest beta estimated for the swap rate is highly positively correlated with the beta estimated for 1 year LIBOR. Their Spearman rank correlation is $50.08 \%$ and their Pearson correlation is $47.16 \%$. Despite this fact, the interest beta from the swap rates is highly negatively correlated with both interest betas estimated on the treasuries. Their Spearman correlations are $-46.08 \%$ for 1-year treasuries and $-67.15 \%$ for 7 -year treasuries.. This could be explained by swap positions of the banks, e.g., banks that take a fixed side of the swap rate payers automatically become counterparties to the floating treasuries-rate payers. However, this explanation is not valid for positive correlations among swap rate and LIBOR exposures. Another important thing worth mentioning is that interest betas for LIBOR rates are highly positively correlated. Nonetheless, the interest beta from shorter maturity LIBOR has positive correlations with the interest betas of the treasuries, while that of longer maturity LIBOR has negative correlations with the interest beta of the treasuries.

\subsection{The effects of MMs on volume (second stage estimation)}

Table 5 presents the results of GLS estimates of the relationship between our measures of industry-adjusted volume and the implied MMs as presented in Equation (4). These estimates are made for the five alternative interest returns: (3-month LIBOR, 1-year LIBOR, 1-year Treasury, 7-year Treasury and 7-year swap rate). Two models are presented in the Table, labelled (a), and (b). In all models the dependent variable is the same - the logarithm of the bank's industry-adjusted turnover.

Model (a) is our basic model, which includes the following variables: absolute value of interest beta, absolute value of CAPM beta, absolute value of market-to-book beta $(\mathrm{SMB})$, absolute value of size beta $(\mathrm{HML})$, opening stock price, dividend yield, bank

\footnotetext{
${ }^{14}$ Beta estimates are not directly comparable, that is, in principle the coefficient for a 7-year Treasury rate risk and that of a 7-year swap rate could signal the equivalent 7-year maturity mismatches in a dollar amount. So, while the signs of the imputed betas should coincide with the signs of the actual exposures, the sizes (absolute values) of betas can tell us little about the sizes (absolute values) of actual mismatches in the cross-section. In other words, beta estimates of the different rates but of the same maturity may signify the same size of the actual mismatch; the ratio at which each beta could be precisely converted into the actual mismatch of the corresponding maturity is, however, unknown and might be time dependent. Still, information contained in absolute values of interest rate betas is fairly useful for comparisons of changes in actual exposure over time for separate banks.
} 
size (market capitalization), and firm and time fixed effects. Model (b) also includes return volatility, daily returns autocovariance (we follow Roll (1984), who suggests applying autocovariance as a measure of effective bid-ask spread), absolute value of abnormal returns (measured by Jensen's alpha), and absolute value of unexpected returns, measured by the disturbance estimates $\left(\varepsilon_{i t}\right)$ from Equation (1). In Table 5 heteroscedasticity robust standard errors clustered by bank are reported in brackets. ${ }^{15}$ All data is winsorized at $0.5 \% .{ }^{16}$

First note that all the estimates of the coefficients of the interest rate betas, i.e., the implied MMs, from all the regressions models presented in Table 5 are significantly positive indicating that higher implied MMs induce higher turnover. The implied MM in Table 5 range from 0.0116 to 0.0369 . In other words, a $1 \%$ change in stock return sensitivity by entails an increase of $0.0116 \%$ to $0.0369 \%$ in turnover. We note that the introduction of more variables lowers the estimated implied MMs but they remain significant and of the same order of magnitude. The $\mathrm{R}^{2}$ s of all the models are around $80 \%$, indicating a good fit.

Interestingly, as the coefficients values indicate, the magnitude of the effect of market beta on turnover is either insignificantly different from zero or negative, whereas the betas of the market-to-book (HML) and size (SMB) are generally significant in all models, with HML beta coefficients being generally higher than the coefficients of the interest betas.

As we examine the effect of the explanatory variables, we note the varying pattern effects of the MMs. First, Table 5 reveals that for both models (a) and (b) all the controls except for return volatility and the autocovariance are highly significant (at $1 \%$ or better), and all the variables without exception have the expected effect on turnover. Secondly, agreeing with our conjectures, the errors' idiosyncratic risk and the abnormal expected returns (the absolute values of the alphas), boost trading activity in all five classes of interest.

\subsection{MMs and returns}

In this part we examine whether the detected positive relationship between turnover and the implied MMs can be attributed to the effect of MMs on contemporaneous absolute values of returns, which in turn affect trading volume. For that purpose, we add marginal interest returns (product of interest rate beta and change in interest rate) as controls to all the specifications of Table 5 . We hypothesize that, after controlling for marginal returns, the coefficients $\gamma_{1}$ remain significantly positive, thus indicating that the expected price effects of interest risk subsume little or naught from the effects of MMs on volume.

\footnotetext{
${ }^{15}$ See the argument by Petersen (2009) as to why clustering by bank and using time effects is optimal for having unbiased standard errors in wide panels characterized by a large number of banks and a small number of time points.

${ }^{16}$ For the sake of presentation simplicity, the tables do not report the regressions intercepts.
} 
The results of models $(a)$ and $(b)$, which include the marginal returns, are presented in Table 6. One observes that in all the models the coefficients of the MMs are positive and highly significant, while the coefficients of the marginal returns are not; in various specifications they are not significantly different from zero, in others they are sometimes negative and sometimes positive. This confirms our hypothesis that the MMs affect turnover beyond their expected effect on returns, and thus contribute to disagreement between investors regardless of their effect on prices.

\subsection{Robustness checks}

We next present further tests to rule out the possibility that the effect of MMs on trading stems from their effects on returns. We employ Kandel and Pearson's (1995) methodology of testing for turnover differences between non-event (smallest or no MMs) and event samples (largest MM). Thus, we split the sample into deciles according to actual returns and absolute MMs. Within each return decile, we test for the difference in mean turnover between the smallest and the largest MM deciles (applying t-tests). Table 7 presents the results of some of these tests. In Panel A we present the full statistics for one class of MMs, the 1-year Treasury interest rates. One observes from this panel that within each return decile, the largest MMs sample yields consistently higher mean turnover, and the difference in mean turnover between the largest MMS and the smallest or no MMs is highly statistically significant $(p<0.0001)$. This result implies that even when there is no (or negligible) change in price, the mean turnover in the largest MMs sample is significantly higher than in the smallest or no MMs. This reinforces our claim that investor disagreement rather than returns is a key explanation for the observed patterns in the data. The same conclusions are gleaned from Panel B of Table 7 which repeats the above analysis for the other four classes of interest rates. ${ }^{17}$

Robustness tests were also conducted using alternative specifications of Equation (4). The results of these tests are presented in the five panels of Table 8 (for brevity we report just the most salient statistics), where each panel corresponds to a different specification. Panel A presents results when the CAPM model is used to compute the betas. Panel $B$ shows the alternative measures of beta, i.e., log-linear specification of the model where, for ease of comparison of the coefficients, all betas are normalized by their corresponding standard errors. Panel $C$ shows the outcome of log-log specification where estimation is conducted only on rolling windows having 48 months each. Panel D presents the output of the model in which log of standard deviation of analyst EPS forecasts normalized by opening price is used as a dependent variable. Panel $E$ presents the output of the model in which log of standard deviation of analyst EPS forecasts normalized by absolute value of mean EPS forecast is used as a dependent variable.

\footnotetext{
${ }^{17}$ In order to conserve space not all the statistics shown in in Panel A are also presented in Panel B.
} 
The various panels differ also in the controls used. Panel A uses CAPM beta, dividend-to-price, capitalization and price as controls. Panels B and C use CAPM beta, HML beta, SMB beta, dividend-to-price, capitalization and price as controls. Panels $C$ and $E$ use CAPM beta, HML beta, SMB beta and a number of analyst forecasts as controls. The estimation method used is generalized least squares (GLS). Heteroscedasticity robust t-statistics clustered by bank are reported in brackets. All models use time and fixed effects. Time effects are month and year dummies.

One observes in all panels that the estimated interest rate betas are all significantly positive, confirming our hypothesis that the implied MMs increase investor disagreement.

\section{CONCLUSION}

In classical financial theory the exposure of a firm's return to interest rate risks is constant, and therefore it should not affect pricing. This, however, is not the case for financial institutions whose day-to-day decision making implies time varying shifts in the composition of interest risks that are very sensitive to maturity mismatches (MMs). In this paper we argue that since larger MMs are positively correlated with opacity and sophistication of portfolio compositions of the banks, MMs induce a perception of uncertainty and ambiguity about the banks' performance and therefore provide more grounds on which investors may disagree. However, evaluation of MMs using information from financial reports entails serious deficiencies, since such reports do not contain sufficient information (because of extensive off-balance sheet positions, basis risk, prepayment of loans, etc.). The approach we used in this paper to circumvent this problem was to proxy implied MMs by stock return sensitivities to changes in interest rates. We found a significant positive relationship between the implied MMs of banks traded on AMEX, NYSE and NASDAQ and their stock turnover. This effect is preserved after controlling for standard determinants of trading volume and for marginal interest returns in contemporaneous periods.

Our paper still leaves a number of avenues for future research. First, whereas we have shown that investor disagreement increases with MMs, it has not been shown how and why this phenomenon occurs. An increase in trading can be attributed to one or more theories of investor disagreement (e.g., gradual information flow, limited attention, overconfidence and heterogeneous priors); identifying the precise channels of the effect requires gathering data on individual investors and their trading patterns. . Second, one may wonder whether the disagreement between investors and managers may also affect volume. . Second, one may wonder whether the disagreement between investors and managers may also affect volume. These interesting questions however are task beyond the space of this paper and are left for future research. 
Table 1. Descriptive statistics and correlations of returns

Panel A: Summary statistics

\begin{tabular}{llllllll}
\hline Return & $\mathrm{N}$ & Mean (\%) & Std. Dev. & Min & Max & Skewness & Kurtosis \\
\hline bank return & 270,981 & 0.81235 & 0.1417657 & -0.93333 & 11 & 156.9086 & $52,878.58$ \\
S\&P500 return & 180 & 0.32793 & 0.0447173 & -0.16942 & 0.107723 & -0.54757 & 3.783146 \\
treasury 1 year & 180 & 0.23544 & 0.0028278 & -0.00331 & 0.013061 & 1.028052 & 4.409037 \\
treasury 7 year & 180 & 0.47705 & 0.0176322 & -0.04695 & 0.081895 & 0.1185403 & 4.602073 \\
LIBOR 3 month & 180 & -1.14183 & 0.1013871 & -0.43846 & 0.471423 & -0.2193746 & 8.008165 \\
LIBOR 1 year & 180 & -0.90169 & 0.0760415 & -0.25497 & 0.252964 & 0.0425271 & 4.550293 \\
swap 7 year & 161 & -0.40041 & 0.0776338 & -0.30028 & 0.288591 & 0.4874431 & 5.72525 \\
\hline
\end{tabular}

Panel B: Correlation matrix of returns

\begin{tabular}{lllllll}
\hline & market & 1y Treasury & 7y Treasury & 3m LIBOR & 1y LIBOR & 7y swap \\
\hline Market & 1.000 & -0.286 & -0.361 & -0.073 & -0.001 & 0.215 \\
1 year Treasury & -0.309 & 1.000 & 0.569 & -0.127 & -0.291 & -0.290 \\
7 year Treasury & -0.345 & 0.564 & 1.000 & -0.070 & -0.246 & -0.584 \\
3 month LIBOR & -0.119 & -0.184 & -0.075 & 1.000 & 0.834 & 0.192 \\
1 year LIBOR & 0.008 & -0.415 & -0.331 & 0.781 & 1.000 & 0.430 \\
7 year swap & 0.183 & -0.315 & -0.609 & 0.101 & 0.416 & 1.000 \\
\hline
\end{tabular}

Panel A presents summary statistics of monthly returns. See the text for the definition of variables. Except for swap 7 year returns, all data are for the period from January 1999 to December 2013. For swaps, they are from September 2000 to December 2013. Panel B presents return correlations. Pearson's correlations appear below the diagonal and Spearman's rank correlations appear above the diagonal. 
Table 2. Summary statistics of bank specific variables

\begin{tabular}{|c|c|c|c|c|c|c|c|}
\hline Variable & $\mathrm{N}$ & Mean & Std. Dev. & Min & $\operatorname{Max}$ & Skewness & Kurtosis \\
\hline $\begin{array}{ll}\text { total } & \text { shares } \\
\text { outstanding }(000 \mathrm{~s})\end{array}$ & 45,471 & $82,329.58$ & $522,023.9$ & 450 & $1.78 \mathrm{E}+07$ & 19.08 & 495.91 \\
\hline $\begin{array}{l}\text { total trading volume } \\
\text { (000s) }\end{array}$ & 45,471 & $7,282.36$ & $98,854.12$ & 0.2 & $1.02 \mathrm{E}+07$ & 55.51 & $4,156.58$ \\
\hline monthly turnover & 45,471 & 0.06 & 0.08 & 5.42E-05 & 2.344 & 6.49 & 81.59 \\
\hline $\begin{array}{l}\text { capitalization } \\
(\$ 000 s)\end{array}$ & 45,471 & $1,879,59$ & $1.04 \mathrm{E}+07$ & 496.98 & $2.41 \mathrm{E}+08$ & 11.19 & 159.67 \\
\hline price $(\$)$ & 45,471 & 17.1 & 14.09 & 0.1 & 504.69 & 5.95 & 99.95 \\
\hline $\begin{array}{l}\text { total dividend yield } \\
\text { (\$) }\end{array}$ & 45,471 & 0.8 & 0.58 & 0 & 10 & 2.52 & 20.88 \\
\hline standard deviation & 45,471 & 0.04 & 0.19 & 0 & 33.22 & 128.2 & $20,049.58$ \\
\hline Autocovariance & 45,471 & -0.01 & 0.87 & -183.02 & 0.013 & -207.5 & $43,749.21$ \\
\hline $\begin{array}{l}\text { dispersion of EPS } \\
\text { forecasts }\end{array}$ & 14,318 & 0.2162 & 1.1647 & 0.001 & 49.21 & 23.385 & 800.5691 \\
\hline mean EPS forecast & 14,318 & 2.0326 & 5.7882 & -174.7 & 56.43 & -5.555 & 205.7528 \\
\hline number of analysts & 14,318 & 7.9381 & 6.4321 & 2 & 37 & 1.4291 & 4.6117 \\
\hline
\end{tabular}

The table describes summary statistics of variables other than those estimated by the equation (1) for the period from January 2000 to December 2012. Shares outstanding is the total shares outstanding as indicated on the balance sheet adjusted for stock splits and ADR conversion ratio in a given month. Trading volume is the sum of daily volume of a stock traded on all stock exchanges in a given month. Monthly turnover is the sum of daily turnover which is defined as the ratio of trading volume to shares outstanding on a given day. Capitalization is computed as a product of shares outstanding and opening price on the first day of a given month. Price is the opening monthly price in a given month. Dividend is a total per share dividend distribution over the last calendar year. Volatility is a standard deviation of a daily stock return in a given month. Autocovariance is first order autocovariance in daily returns in a given month. Dispersion of earnings per share (EPS) forecasts is standard deviation of analysts' long term (12 months ahead) EPS forecasts. Mean EPS forecast is a simple average of analysts' EPS forecasts. Number of analysts is the number of analysts based on whom the mean EPS forecast is computed. All the data are presented before winsorization.

Table 3. Summary statistics of coefficients estimated by moving windows procedure in equation (1)

\begin{tabular}{|c|c|c|c|c|c|c|}
\hline Var. & Equation & $\mathrm{N}$ & Mean & Std. Dev. & Min & Max \\
\hline \multirow{5}{*}{ 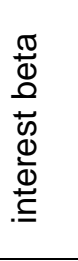 } & libor 3 month & 45,471 & -0.028699 & 0.2753671 & -28.1357 & 2.93844 \\
\hline & libor 1 year & 45,471 & -0.066486 & 0.2113216 & -3.51409 & 12.23115 \\
\hline & treasury 1 year & 45,471 & 1.99365 & 11.10982 & -399.859 & 1043.701 \\
\hline & treasury 7 year & 45,471 & 0.1930636 & 1.134057 & -42.7082 & 44.05197 \\
\hline & swap 7 year & 33,523 & -0.083321 & 0.7365496 & -8.16373 & 78.24302 \\
\hline \multirow{5}{*}{ 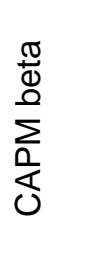 } & libor 3 month & 45,471 & 0.6487412 & 0.6497398 & -13.148 & 16.2623 \\
\hline & libor 1 year & 45,471 & 0.6636418 & 0.6546981 & -6.53234 & 16.24798 \\
\hline & treasury 1 year & 45,471 & 0.6862281 & 0.6633411 & -8.01359 & 16.68794 \\
\hline & treasury 7 year & 45,471 & 0.6881732 & 0.6583725 & -5.47522 & 17.07118 \\
\hline & swap 7 year & 33,523 & 0.6638898 & 0.6555041 & -5.46204 & 16.72149 \\
\hline$\sum_{\infty} \infty$ & libor 3 month & 45,471 & 0.3722266 & 1.087224 & -93.6242 & 10.11503 \\
\hline
\end{tabular}




\begin{tabular}{|c|c|c|c|c|c|c|}
\hline & libor 1 year & 45,471 & 0.376794 & 1.240512 & -110.196 & 10.20944 \\
\hline & treasury 1 year & 45,471 & 0.363119 & 1.177353 & -107.971 & 10.18982 \\
\hline & treasury 7 year & 45,471 & 0.3687886 & 1.212374 & -106.896 & 10.62877 \\
\hline & swap 7 year & 33,523 & 0.3293167 & 1.105185 & -90.1402 & 10.44012 \\
\hline \multirow{5}{*}{ 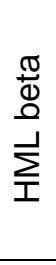 } & libor 3 month & 45,471 & 0.2916107 & 1.443909 & -15.1877 & 166.0134 \\
\hline & libor 1 year & 45,471 & 0.3047995 & 1.413549 & -13.9012 & 154.2205 \\
\hline & treasury 1 year & 45,471 & 0.3221886 & 1.384499 & -13.4294 & 155.2885 \\
\hline & treasury 7 year & 45,471 & 0.3026157 & 1.39251 & -8.8904 & 152.3229 \\
\hline & swap 7 year & 33,523 & 0.3258248 & 1.438025 & -12.0325 & 149.6964 \\
\hline \multirow{5}{*}{ 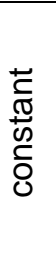 } & libor 3 month & 45,471 & 0.0041049 & 0.0182736 & -0.11843 & 1.142008 \\
\hline & libor 1 year & 45,471 & 0.0040072 & 0.025445 & -0.11398 & 2.650547 \\
\hline & treasury 1 year & 45,471 & 0.0004797 & 0.0333444 & -0.22545 & 3.330951 \\
\hline & treasury 7 year & 45,471 & 0.0035839 & 0.0255549 & -0.1284 & 2.407672 \\
\hline & swap 7 year & 33,523 & 0.0045496 & 0.0279515 & -0.14944 & 2.815912 \\
\hline
\end{tabular}

The table presents summary statistics of coefficients estimated by the rolling window procedure in the equation (1): interest betas, CAPM betas, SMB betas, HML betas and intercept terms. The column "equation" specifies interest rate used for estimation of the equation (1). All the data are presented before winsorization. 
Table 4. Correlation matrix of interest betas and CAPM betas [I tried to change "libor" to "LIBOR" like in the rest of the tables but it moved the column - maybe you can do it]

\begin{tabular}{|c|c|c|c|c|c|c|c|c|c|c|c|}
\hline & \multicolumn{5}{|c|}{ interest beta } & \multicolumn{5}{|c|}{ CAPM beta } \\
\hline & & $\operatorname{tr} 1 \mathrm{y}$ & $\operatorname{tr} 7 y$ & lib $3 m$ & lib 1y & sw 7y & $\operatorname{tr} 1 y$ & $\operatorname{tr} 7 y$ & lib $3 m$ & lib 1y & sw $7 y$ \\
\hline \multirow{5}{*}{ 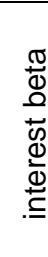 } & treasury 1 year & 1 & 0.7303 & 0.1529 & -0.1248 & -0.4608 & 0.0648 & 0.0896 & -0.0883 & -0.0707 & -0.0284 \\
\hline & treasury 7 year & 0.6067 & 1 & 0.1051 & -0.2199 & -0.6715 & -0.1343 & -0.0408 & -0.2719 & -0.2493 & -0.2076 \\
\hline & LIBOR 3 month & 0.1172 & 0.032 & 1 & 0.6678 & 0.0524 & 0.127 & 0.1333 & 0.0959 & 0.0821 & 0.116 \\
\hline & LIBOR 1 year & -0.0754 & -0.2049 & 0.6776 & 1 & 0.5008 & 0.0986 & 0.0926 & 0.141 & 0.1109 & 0.1446 \\
\hline & swap 7 year & -0.3168 & -0.6209 & 0.0644 & 0.4716 & 1 & 0.1454 & 0.0805 & 0.2514 & 0.2177 & 0.179 \\
\hline \multirow{5}{*}{ 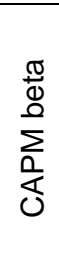 } & treasury 1 year & 0.193 & -0.0243 & 0.1342 & 0.0654 & 0.0025 & 1 & 0.9791 & 0.9726 & 0.9793 & 0.9691 \\
\hline & treasury 7 year & 0.1993 & 0.0541 & 0.1271 & 0.0745 & -0.0315 & 0.9825 & 1 & 0.9568 & 0.9644 & 0.9698 \\
\hline & LIBOR 3 month & 0.0662 & -0.1602 & 0.1073 & 0.1127 & 0.1091 & 0.9749 & 0.9709 & 1 & 0.9967 & 0.9832 \\
\hline & LIBOR 1 year & 0.0789 & -0.1377 & 0.0912 & 0.0826 & 0.073 & 0.9808 & 0.9765 & 0.9972 & 1 & 0.9848 \\
\hline & swap 7 year & 0.1126 & -0.0932 & 0.1241 & 0.1048 & 0.0246 & 0.9745 & 0.9803 & 0.9861 & 0.9879 & 1 \\
\hline
\end{tabular}

Pearson's correlations appear below the diagonal and Spearman's rank correlations appear above the diagonal. 
Table 5. GLS estimation of industry adjusted turnover on interest rate risk (log-log)

\begin{tabular}{|c|c|c|c|c|c|c|c|c|c|c|}
\hline & \multicolumn{2}{|c|}{ LIBOR 3 month } & \multicolumn{2}{|c|}{ LIBOR 1 year } & \multicolumn{2}{|c|}{ Treasury 1 year } & \multicolumn{2}{|c|}{ Treasury 7 year } & \multicolumn{2}{|c|}{ Swap 7 year } \\
\hline & (a) & (b) & (a) & (b) & (a) & (b) & (a) & (b) & (a) & (b) \\
\hline interest beta & $\begin{array}{l}0.0145^{\star * *} \\
(0.0043)\end{array}$ & $\begin{array}{l}0.0116^{\star * *} \\
(0.0042)\end{array}$ & $\begin{array}{l}0.0366^{* * *} \\
(0.005)\end{array}$ & $\begin{array}{l}0.0313^{\star * \star} \\
(0.0049)\end{array}$ & $\begin{array}{l}0.0369^{\star * *} \\
(0.0042)\end{array}$ & $\begin{array}{l}0.0253^{\star * *} \\
(0.0045)\end{array}$ & $\begin{array}{l}0.0214^{\star * *} \\
(0.0051)\end{array}$ & $\begin{array}{l}0.0154^{\star * *} \\
(0.005)\end{array}$ & $\begin{array}{l}0.0295^{\star * *} \\
(0.0054)\end{array}$ & $\begin{array}{l}0.0236^{* * *} \\
(0.0052)\end{array}$ \\
\hline CAPM beta & $\begin{array}{l}-0.0122^{*} \\
(0.0062)\end{array}$ & $\begin{array}{l}-0.0124^{* *} \\
(0.0061)\end{array}$ & $\begin{array}{l}-0.0167^{\star * *} \\
(0.0063)\end{array}$ & $\begin{array}{l}-0.0155^{\star *} \\
(0.0063)\end{array}$ & $\begin{array}{l}0.0002 \\
(0.007)\end{array}$ & $\begin{array}{l}-0.0019 \\
(0.0068)\end{array}$ & $\begin{array}{l}0.0095 \\
(0.0077)\end{array}$ & $\begin{array}{l}0.0068 \\
(0.0075)\end{array}$ & $\begin{array}{l}0.0042 \\
(0.0067)\end{array}$ & $\begin{array}{l}0.0038 \\
(0.0066)\end{array}$ \\
\hline SMB beta & $\begin{array}{l}0.0149 * * * \\
(0.0042)\end{array}$ & $\begin{array}{l}0.0133^{\star \star *} \\
(0.0041)\end{array}$ & $\begin{array}{l}0.0192^{\star \star *} \\
(0.0041)\end{array}$ & $\begin{array}{l}0.0177^{\star \star \star} \\
(0.0041)\end{array}$ & $\begin{array}{l}0.0251^{* * *} \\
(0.0043)\end{array}$ & $\begin{array}{l}0.0221^{\star * *} \\
(0.0042)\end{array}$ & $\begin{array}{l}0.0265^{\star \star \star} \\
(0.004)\end{array}$ & $\begin{array}{l}0.0248^{\star * *} \\
(0.0039)\end{array}$ & $\begin{array}{l}0.0205 \\
(0.016)\end{array}$ & $\begin{array}{l}0.019 \\
(0.0158)\end{array}$ \\
\hline HML beta & $\begin{array}{l}0.0458^{* * *} \\
(0.0051)\end{array}$ & $\begin{array}{l}0.0423^{* * *} \\
(0.005)\end{array}$ & $\begin{array}{l}0.0482^{* \star *} \\
(0.0053)\end{array}$ & $\begin{array}{l}0.044^{* * *} \\
(0.0051)\end{array}$ & $\begin{array}{l}0.0377^{\star * *} \\
(0.0052)\end{array}$ & $\begin{array}{l}0.0331^{\star * *} \\
(0.0052)\end{array}$ & $\begin{array}{l}0.0434^{\star * *} \\
(0.0051)\end{array}$ & $\begin{array}{l}0.0401^{* * *} \\
(0.0051)\end{array}$ & $\begin{array}{l}0.1486^{\star * *} \\
(0.0145)\end{array}$ & $\begin{array}{l}0.1375^{\star * *} \\
(0.0144)\end{array}$ \\
\hline price & $\begin{array}{l}- \\
0.1595^{\star * *} \\
(0.0424)\end{array}$ & $\begin{array}{l}-0.1404^{* * *} \\
(0.0421)\end{array}$ & $\begin{array}{l}-0.1395^{\star * *} \\
(0.042)\end{array}$ & $\begin{array}{l}- \\
0.1154^{* * *} \\
(0.0418)\end{array}$ & $\begin{array}{l}- \\
0.1414^{* \star *} \\
(0.042)\end{array}$ & $\begin{array}{l}- \\
0.1269^{\star \star *} \\
(0.0414)\end{array}$ & $\begin{array}{l}-0.1422^{* * *} \\
(0.0425)\end{array}$ & $\begin{array}{l}- \\
0.1266^{* * *} \\
(0.0422)\end{array}$ & $\begin{array}{l}-0.0848^{\star *} \\
(0.0409)\end{array}$ & $\begin{array}{l}-0.0605 \\
(0.041)\end{array}$ \\
\hline div-to-price & $\begin{array}{l}1.375^{\star * *} \\
(0.204)\end{array}$ & $\begin{array}{l}1.2117^{\star * *} \\
(0.2158)\end{array}$ & $\begin{array}{l}1.3715^{\star * *} \\
(0.2038)\end{array}$ & $\begin{array}{l}1.1963^{\star * *} \\
(0.2143)\end{array}$ & $\begin{array}{l}1.4185^{\star * *} \\
(0.2066)\end{array}$ & $\begin{array}{l}1.2733^{\star * *} \\
(0.2218)\end{array}$ & $\begin{array}{l}1.4149^{* * *} \\
(0.2046)\end{array}$ & $\begin{array}{l}1.2797^{\star * *} \\
(0.216)\end{array}$ & $\begin{array}{l}1.3422^{* * *} \\
(0.1966)\end{array}$ & $\begin{array}{l}1.1739^{* * *} \\
(0.2071)\end{array}$ \\
\hline capitalization & $\begin{array}{l}0.139^{* * *} \\
(0.0429)\end{array}$ & $\begin{array}{l}0.1633^{\star * *} \\
(0.0454)\end{array}$ & $\begin{array}{l}0.1291^{* * *} \\
(0.0422)\end{array}$ & $\begin{array}{l}0.154^{* * *} \\
(0.0448)\end{array}$ & $\begin{array}{l}0.1321^{* * *} \\
(0.0425)\end{array}$ & $\begin{array}{l}0.1538^{* * *} \\
(0.045)\end{array}$ & $\begin{array}{l}0.131^{* * *} \\
(0.0425)\end{array}$ & $\begin{array}{l}0.1516^{\star * *} \\
(0.0455)\end{array}$ & $\begin{array}{l}0.1007^{* *} \\
(0.0402)\end{array}$ & $\begin{array}{l}0.1289^{* * *} \\
(0.0438)\end{array}$ \\
\hline volatility & - & $\begin{array}{l}0.3959 \\
(0.2544)\end{array}$ & - & $\begin{array}{l}0.3751 \\
(0.248)\end{array}$ & - & $\begin{array}{l}0.3943 \\
(0.2511)\end{array}$ & - & $\begin{array}{l}0.3993 \\
(0.2537)\end{array}$ & - & $\begin{array}{l}0.3579 \\
(0.2393)\end{array}$ \\
\hline covariance & - & $\begin{array}{l}0.0769^{*} \\
(0.0465)\end{array}$ & - & $\begin{array}{l}0.0733 \\
(0.0453)\end{array}$ & - & $\begin{array}{l}0.0766^{*} \\
(0.0459)\end{array}$ & - & $\begin{array}{l}0.0776^{\star} \\
(0.0464)\end{array}$ & - & $\begin{array}{l}0.0716 \\
(0.0437)\end{array}$ \\
\hline alpha & - & $\begin{array}{l}3.5468^{\star * *} \\
(1.0972)\end{array}$ & - & $\begin{array}{l}3.6879 * * * \\
(1.0827)\end{array}$ & - & $\begin{array}{l}1.7978^{\star *} \\
(0.7119)\end{array}$ & - & $\begin{array}{l}2.1772^{*} \\
(1.1615)\end{array}$ & - & $\begin{array}{l}3.6957^{\star \star \star} \\
(1.1106)\end{array}$ \\
\hline error & - & $\begin{array}{l}0.6246^{* * *} \\
(0.184)\end{array}$ & - & $\begin{array}{l}0.7254^{\star \star \star} \\
(0.1824)\end{array}$ & - & $\begin{array}{l}0.5738^{\star * \star} \\
(0.1458)\end{array}$ & - & $\begin{array}{l}0.5877^{\star * *} \\
(0.1747)\end{array}$ & - & $\begin{array}{l}0.9349^{* * *} \\
(0.1553)\end{array}$ \\
\hline time effects & yes & Yes & yes & yes & yes & yes & yes & yes & yes & yes \\
\hline fixed effects & yes & Yes & yes & yes & yes & yes & yes & yes & yes & yes \\
\hline $\mathrm{N}$ & 45,471 & 45,471 & 45,471 & 45,471 & 45,471 & 45,471 & 45,471 & 45,471 & 33,523 & 33,523 \\
\hline $\mathrm{R} 2$ & 0.7997 & 0.8019 & 0.8009 & 0.8032 & 0.8007 & 0.8027 & 0.8002 & 0.802 & 0.8039 & 0.8062 \\
\hline
\end{tabular}

The table presents results from generalized least squares (GLS) estimation of turnover on interest rate risk and controls. Heteroscedasticity robust standard errors clustered by bank are in brackets. Time effects are month and year dummies. All the data are winsorized at $0.5 \%$. Constant is included into regressions but excluded from the table in sake of for the sake of economy of space. Stars denote significance: $* * \star$ $<0.01^{* *}<0.05^{*}<0.1$ 
Table 6. Betas and marginal returns

\begin{tabular}{|c|c|c|c|c|c|c|c|c|c|c|}
\hline & \multicolumn{2}{|c|}{ LIBOR 3 month } & \multicolumn{2}{|c|}{ LIBOR 1 year } & \multicolumn{2}{|c|}{ Treasury 1 year } & \multicolumn{2}{|c|}{ Treasury 7 year } & \multicolumn{2}{|c|}{ Swap 7 year } \\
\hline & (a) & (b) & (a) & (b) & (a) & (b) & (a) & (b) & (a) & (b) \\
\hline interest beta & $\begin{array}{l}0.016^{\star * *} \\
(0.005)\end{array}$ & $\begin{array}{l}0.0149^{\star \star \star} \\
(0.0051)\end{array}$ & $\begin{array}{l}0.0366^{\star \star \star} \\
(0.0056)\end{array}$ & $\begin{array}{l}0.028^{* * *} \\
(0.0056)\end{array}$ & $\begin{array}{l}0.0142^{\star * \star} \\
(0.0051)\end{array}$ & $\begin{array}{l}0.0149^{\star * *} \\
(0.0053)\end{array}$ & $\begin{array}{l}0.0157^{\star * \star} \\
(0.0054)\end{array}$ & $\begin{array}{l}0.0177^{\star \star \star} \\
(0.0054)\end{array}$ & $\begin{array}{l}0.0142^{\star * \star} \\
(0.005)\end{array}$ & $\begin{array}{l}0.014^{\star \star *} \\
(0.005)\end{array}$ \\
\hline CAPM beta & $\begin{array}{l}0.0032 \\
(0.0068)\end{array}$ & $\begin{array}{l}0.0079 \\
(0.0069)\end{array}$ & $\begin{array}{l}-0.0069 \\
(0.0073)\end{array}$ & $\begin{array}{l}0.0042 \\
(0.0068)\end{array}$ & $\begin{array}{l}0.0126^{\star} \\
(0.0069)\end{array}$ & $\begin{array}{l}0.0177^{\star * *} \\
(0.0068)\end{array}$ & $\begin{array}{l}0.015^{\star *} \\
(0.0072)\end{array}$ & $\begin{array}{l}0.0174^{\star *} \\
(0.0073)\end{array}$ & $\begin{array}{l}0.0014 \\
(0.0067)\end{array}$ & $\begin{array}{l}0.0097 \\
(0.0065)\end{array}$ \\
\hline SMB beta & $\begin{array}{l}0.0031 \\
(0.0045)\end{array}$ & $\begin{array}{l}-0.002 \\
(0.0044)\end{array}$ & $\begin{array}{l}0.0085 \\
(0.0043)\end{array}$ & $\begin{array}{l}0.0016 \\
(0.0043)\end{array}$ & $\begin{array}{l}0.0078^{*} \\
(0.0045)\end{array}$ & $\begin{array}{l}0.0027 \\
(0.0044)\end{array}$ & $\begin{array}{l}0.009^{* *} \\
(0.0042)\end{array}$ & $\begin{array}{l}0.0014 \\
(0.0042)\end{array}$ & $\begin{array}{l}0.008^{*} \\
(0.0045)\end{array}$ & $\begin{array}{l}0.0041 \\
(0.0045)\end{array}$ \\
\hline HML beta & $\begin{array}{l}0.017^{\star \star \star} \\
(0.0057)\end{array}$ & $\begin{array}{l}0.0162^{\star * *} \\
(0.0056)\end{array}$ & $\begin{array}{l}0.0206^{\star * *} \\
(0.0056)\end{array}$ & $\begin{array}{l}0.0151^{* * *} \\
(0.0054)\end{array}$ & $\begin{array}{l}0.0205^{\star * \star} \\
(0.0058)\end{array}$ & $\begin{array}{l}0.0201^{\star * *} \\
(0.0057)\end{array}$ & $\begin{array}{l}0.0181^{* * *} \\
(0.0056)\end{array}$ & $\begin{array}{l}0.0135^{\star \star} \\
(0.0054)\end{array}$ & $\begin{array}{l}0.015^{\star \star \star} \\
(0.0055)\end{array}$ & $\begin{array}{l}0.011^{\star *} \\
(0.0052)\end{array}$ \\
\hline $\begin{array}{l}\text { interest } \\
\text { marginal return }\end{array}$ & $\begin{array}{l}0.0626 \\
(0.0443)\end{array}$ & $\begin{array}{l}0.0052 \\
(0.0569)\end{array}$ & $\begin{array}{l}0.2183 \\
(0.3322)\end{array}$ & $\begin{array}{l}0.5206 \\
(0.3293)\end{array}$ & $\begin{array}{l}-0.0806 \\
(0.0757)\end{array}$ & $\begin{array}{l}0.003 \\
(0.1295)\end{array}$ & $\begin{array}{l}0.1091^{\star *} \\
(0.0521)\end{array}$ & $\begin{array}{l}0.0637 \\
(0.1206)\end{array}$ & $\begin{array}{l}1.1171^{* \star *} \\
(0.3033)\end{array}$ & $\begin{array}{l}0.3447 \\
(0.3066)\end{array}$ \\
\hline $\begin{array}{l}\text { CAPM } \\
\text { marginal return }\end{array}$ & $\begin{array}{l}-0.1674 \\
(0.2284)\end{array}$ & $\begin{array}{l}-1.3253^{\star \star \star} \\
(0.2573)\end{array}$ & $\begin{array}{l}-0.0576 \\
(0.2374)\end{array}$ & $\begin{array}{l}- \\
1.4237^{* \star *} \\
(0.2486)\end{array}$ & $\begin{array}{l}-0.1114 \\
(0.2073)\end{array}$ & $\begin{array}{l}-0.8544^{\star \star} \\
(0.3445)\end{array}$ & $\begin{array}{l}-0.1785 \\
(0.1931)\end{array}$ & $\begin{array}{l}-0.8652^{\star \star *} \\
(0.2681)\end{array}$ & $\begin{array}{l}-0.2661 \\
(0.2484)\end{array}$ & $\begin{array}{l}- \\
1.6846^{\star * *} \\
(0.258)\end{array}$ \\
\hline $\begin{array}{l}\mathrm{SMB} \text { marginal } \\
\text { return }\end{array}$ & $\begin{array}{l}-0.2634 \\
(0.1908)\end{array}$ & $\begin{array}{l}0.1455 \\
(0.2016)\end{array}$ & $\begin{array}{l}-0.6288^{\star \star} \\
(0.2539)\end{array}$ & $\begin{array}{l}0.1025 \\
(0.2961)\end{array}$ & $\begin{array}{l}-0.4838^{* *} \\
(0.2368)\end{array}$ & $\begin{array}{l}0.1096 \\
(0.2796)\end{array}$ & $\begin{array}{l}-0.4924^{* *} \\
(0.206)\end{array}$ & $\begin{array}{l}0.1877 \\
(0.2621)\end{array}$ & $\begin{array}{l}-0.5051 \\
(0.3199)\end{array}$ & $\begin{array}{l}-0.1197 \\
(0.3311)\end{array}$ \\
\hline $\begin{array}{l}\mathrm{HML} \text { marginal } \\
\text { return }\end{array}$ & $\begin{array}{l}-0.0586 \\
(0.0718)\end{array}$ & $\begin{array}{l}0.0275 \\
(0.1095)\end{array}$ & $\begin{array}{l}- \\
0.2729^{\star \star \star} \\
(0.0988)\end{array}$ & $\begin{array}{l}0.5915^{\star} \\
(0.3425)\end{array}$ & $\begin{array}{l}-0.0753 \\
(0.1066)\end{array}$ & $\begin{array}{l}0.0013 \\
(0.1596)\end{array}$ & $\begin{array}{l}-0.2148^{\star \star} \\
(0.0977)\end{array}$ & $\begin{array}{l}0.5994^{*} \\
(0.3265)\end{array}$ & $\begin{array}{l}-0.0317 \\
(0.3074)\end{array}$ & $\begin{array}{l}0.6019^{\star} \\
(0.3208)\end{array}$ \\
\hline time effects & yes & yes & yes & yes & yes & yes & yes & yes & yes & yes \\
\hline fixed effects & yes & yes & yes & yes & yes & yes & yes & yes & yes & yes \\
\hline N & 45,471 & 45,471 & 45,471 & 45,471 & 45,471 & 45,471 & 45,471 & 45,471 & 33,523 & 33,523 \\
\hline $\mathrm{R} 2$ & 0.838 & 0.846 & 0.8391 & 0.8468 & 0.8383 & 0.8463 & 0.8383 & 0.846 & 0.8382 & 0.8465 \\
\hline
\end{tabular}

The table presents results from generalized least squares (GLS) estimation of turnover on betas and controls. Marginal returns are absolute values of multiplication of betas and their corresponding risk factors, e.g. HML marginal return is absolute value of multiplication of $\mathrm{HML}$ beta and change in HML factor. Not displayed firm specific controls in basic model (a) are price, capitalization and dividend-to-price. Not displayed firm specific controls in the full model (b) are price, capitalization, dividend-to-price, volatility, autocovariance, alpha and residuals. Heteroscedasticity robust standard errors clustered by bank are in brackets. Time effects are month and year dummies. All the data are winsorized at $0.5 \%$. Constant is included into regressions but excluded from the table in sake of space. Stars denote significance: ${ }^{* * *}<0.01^{* *}<0.05^{*}<0.1$ 
Table 7. Mean turnover across MM and return deciles

Panel A: 1 year Treasury bond

\begin{tabular}{l|l|ll|ll|l}
\hline \multirow{2}{*}{$\begin{array}{l}\text { Return } \\
\text { decile }\end{array}$} & Return range & \multicolumn{2}{|l|}{ Smallest MM decile } & \multicolumn{2}{l|}{ Largest MM decile } & P-value \\
\cline { 3 - 5 } & & $\mathrm{N}$ & mean & $\mathrm{N}$ & mean & \\
\hline 1 & $\mathrm{R}<-0.0769$ & 495 & 0.0667 & 578 & 0.1655 & $<0.0001$ \\
2 & $-0.0769<\mathrm{R}<-0.0381$ & 475 & 0.0459 & 469 & 0.1015 & $<0.0001$ \\
3 & $-0.0381<\mathrm{R}<-0.01723$ & 489 & 0.0433 & 412 & 0.0867 & $<0.0001$ \\
4 & $-0.0172<\mathrm{R}<-0.0034$ & 504 & 0.0437 & 374 & 0.0702 & $<0.0001$ \\
5 & $-0.0034<\mathrm{R}<0.008$ & 420 & 0.0418 & 354 & 0.0731 & $<0.0001$ \\
6 & $0.008<\mathrm{R}<0.0193$ & 419 & 0.0453 & 369 & 0.0686 & $<0.0001$ \\
7 & $0.0193<\mathrm{R}<0.0323$ & 390 & 0.0425 & 419 & 0.0757 & $<0.0001$ \\
8 & $0.0323<\mathrm{R}<0.0508$ & 402 & 0.0458 & 445 & 0.0702 & $<0.0001$ \\
9 & $0.0508<\mathrm{R}<0.0874$ & 474 & 0.0538 & 513 & 0.0938 & $<0.0001$ \\
10 & $0.0874<\mathrm{R}$ & 479 & 0.0715 & 613 & 0.1602 & $<0.0001$ \\
\hline
\end{tabular}

Panel B: other MMs

\begin{tabular}{l|ll|ll|ll|ll}
\hline \multirow{2}{*}{$\begin{array}{l}\text { Return } \\
\text { decile }\end{array}$} & \multicolumn{2}{|l|}{ 7 year Treasury } & \multicolumn{2}{|l|}{ 7 year swap } & & \multicolumn{2}{l|}{ 3 month LIBOR } & \multicolumn{2}{l}{ year LIBOR } \\
\cline { 2 - 8 } & smallest & largest & smallest & largest & smallest & largest & smallest & largest \\
\hline 1 & 0.0860 & 0.1235 & 0.0836 & 0.1742 & 0.0764 & 0.1343 & 0.0857 & 0.1306 \\
2 & 0.0596 & 0.0760 & 0.0639 & 0.0813 & 0.0623 & 0.0801 & 0.0578 & 0.0853 \\
3 & 0.0508 & 0.0668 & 0.0536 & 0.0594 & 0.0455 & 0.0638 & 0.0507 & 0.0662 \\
4 & 0.0472 & 0.0595 & 0.0565 & 0.0583 & 0.0418 & 0.0607 & 0.0468 & 0.0670 \\
5 & 0.0446 & 0.0583 & 0.0481 & 0.0536 & 0.0349 & 0.0550 & 0.0436 & 0.0631 \\
6 & 0.0523 & 0.0592 & 0.0500 & 0.0562 & 0.0392 & 0.0609 & 0.0501 & 0.0642 \\
7 & 0.0537 & 0.0610 & 0.0579 & 0.0640 & 0.0417 & 0.0699 & 0.0508 & 0.0762 \\
8 & 0.0530 & 0.0619 & 0.0575 & 0.0590 & 0.0468 & 0.0673 & 0.0521 & 0.0744 \\
9 & 0.0661 & 0.0764 & 0.0676 & 0.0749 & 0.0622 & 0.0737 & 0.0692 & 0.0805 \\
10 & 0.0898 & 0.1313 & 0.0919 & 0.1777 & 0.0893 & 0.1189 & 0.0829 & 0.1203 \\
\hline
\end{tabular}

The table presents mean turnover across return and MM deciles. In panel $\mathrm{A}$, interest betas used to form deciles are recovered from the specification with 1 year Treasury bond. P-values are reported from the two-tailed t-test applied to test the significance of difference in mean turnover between the smallest and the largest MM deciles within each return decile. In panel B, interest beta used to form deciles are recovered from all other specifications except for 1 year Treasury bond. 
Table 8. Alternative specifications (robustness check)

\begin{tabular}{cccccc}
\hline & $\begin{array}{c}\text { 3 month } \\
\text { LIBOR }\end{array}$ & $\begin{array}{c}1 \text { year } \\
\text { LIBOR }\end{array}$ & $\begin{array}{c}\text { 1 year } \\
\text { Treasury }\end{array}$ & $\begin{array}{c}7 \text { year } \\
\text { Treasury }\end{array}$ & 7 year swap \\
\hline \multirow{3}{*}{ interest beta } & 0.0161 & 0.038 & 0.0505 & 0.0268 & 0.0511 \\
& $(3.57)$ & $(7.6)$ & $(10.74)$ & $(5.25)$ & $(9.12)$ \\
$\mathrm{R}^{2}$ & 0.7988 & 0.7993 & 0.8 & 0.7993 & 0.7997 \\
$\mathrm{~N}$ & 45,471 & 45,471 & 45,471 & 45,471 & 33,523
\end{tabular}

Panel B: industry adjusted turnover (log-level)

$\begin{array}{cccccc}\text { interest beta } & 25.7111 & 49.4555 & 13.4125 & 0.9228 & 1.241 \\ & (4.15) & (4.49) & (4.78) & (2.65) & (7.74) \\ \mathrm{R}^{2} & 0.0996 & 0.1024 & 0.1129 & 0.1019 & 0.091 \\ \mathrm{~N} & 45,471 & 45,471 & 45,471 & 45,471 & 33,523\end{array}$

Panel C: industry adjusted turnover (only windows 48 months each)

$\begin{array}{cccccc}\text { interest beta } & 0.0185 & 0.0274 & 0.0378 & 0.0151 & 0.051 \\ & (4.15) & (5.36) & (7.98) & (2.8) & (8.39) \\ \mathrm{R}^{2} & 0.0683 & 0.0686 & 0.0734 & 0.0682 & 0.0667 \\ \mathrm{~N} & 34,012 & 34,012 & 34,012 & 34,012 & 26,927\end{array}$

Panel D: dispersion of EPS forecasts normalized by opening price

$\begin{array}{cccccc}\text { interest beta } & 0.0454 & 0.0468 & 0.0544 & 0.0361 & 0.0415 \\ & (2.1) & (2.63) & (3.47) & (2.18) & (2.08) \\ \mathrm{R}^{2} & 0.5634 & 0.5636 & 0.5555 & 0.5527 & 0.6057 \\ \mathrm{~N} & 14,318 & 14,318 & 14,318 & 14,318 & 10,108\end{array}$

Panel E: dispersion of EPS forecasts normalized by mean EPS forecast

$\begin{array}{cccccc}\text { interest beta } & 0.0384 & 0.0371 & 0.0517 & 0.0502 & 0.0209 \\ & (2.39) & (2.48) & (3.42) & (3.73) & (1.11) \\ \mathrm{R}^{2} & 0.4885 & 0.489 & 0.4843 & 0.4836 & 0.5253 \\ \mathrm{~N} & 14,318 & 14,318 & 14,318 & 14,318 & 10,108\end{array}$

The table presents alternative specifications for the relationship between the MMs and investor disagreement. Panel A presents results when the CAPM model is used to compute betas. Panel B presents results when the market model is used to compute betas. Panel C presents results of the log-linear specification of industry adjusted turnover on market risks? where, for ease of comparison of the coefficients, how this eases comparison? all betas are normalized by their corresponding standard errors. Panel $D$ shows the output of log-log specification where estimation is conducted only on rolling windows having 48 months each. Panel $E$ presents the output of the model in which the log of standard deviation of analyst EPS forecasts normalized by opening price is used as a dependent variable. Panel F presents the output of the model in which log of standard deviation of analyst EPS forecasts normalized by absolute value of mean EPS forecast is used as a dependent variable. Panel A uses CAPM beta, dividend-to-price, capitalization and price as controls. Panels B and C A through D use CAPM beta, HML beta, SMB beta, dividend-to-price, capitalization and price as controls. Panels $C$ and ED use CAPM beta, HML beta, SMB beta and a number of analyst forecasts as controls. The estimation method used is generalized least squares (GLS). Heteroscedasticity robust t-statistics clustered by bank are reported in brackets. All models use time and fixed effects. Time effects are month and year dummies. All the data are winsorized at $0.5 \%$. 


\section{REFERENCES}

Amihud, Y., and H. Mendelson. 1986a. Asset Pricing and the Bid-Ask Spread. Journal of Financial Economics, 17, 223-249.

Amihud, Y., and H. Mendelson. 1986b. Liquidity and Stock Returns. Financial Analysts Journal, 42, 4348.

Angel, James J., 1997, Tick Size, Share Price, and Stock Splits, Journal of Finance 52: 655-681.

Badrinath, S.G., G. Gerald, and K. Jayant. 1989. Patterns of Institutional Investment, Prudence and the Managerial "Safety-net" Hypothesis. Journal of Risk and Insurance. 56, 605-629.

Bamber, Linda Smith. 1987. Unexpected earnings, firm size, and trading volume around quarterly earnings announcements. Accounting Review 62, 510-532.

Bamber, Linda Smith, and Youngsoon S. Cheon. 1995. Differential price and volume reactions to accounting earnings announcements. The Accounting Review 70, 417-441.

Beaver, W. 1968. The Information Content of Annual Earnings Announcements. Empirical Research in Accounting, supplement to the Journal of Accounting Research 6: 67-92.

Blume, L., Easley, D., and O'Hara, M., 1994. Market Statistics and Technical Analysis: The Role of Volume. Journal of Finance 49, 153-181.

Brennan, M., and P. Hughes. 1991. Stock Prices and the Supply of Information. Journal of Finance, 46, 1665-1691.

Carlin, Bruce I., Francis A. Longstaff, and Kyle Matoba. 2014. Disagreement and Stock Prices. Journal of Financial Economics 114: 226-238.

Chae, Joon. 2005. Trading Volume, Information Asymmetry, and Timing Information. The Journal of Finance, Vol. 60, No. 1, pp. 413-442.

Chamberlain, Sandra, John S. Howe, and Helen Popper. 1997. The exchange rate exposure of U.S. and Japanese banking institutions. Journal of Banking and Finance, Volume 21, Issue 6, Pages 871-892.

Choi, Jongmoo Jay, Elyasiani, Elyas and Kopecky, Kenneth J. 1992. The Sensitivity of Bank Stock Returns to Market, Interest and Exchange Rate Risks. Journal of Banking and Finance 16: 9831004.

Chordia, Tarun, Sahn-Wook Huh and Avanidhar Subrahmanyam. 2007. The Cross-Section of Expected Trading Activity. The Review of Financial Studies, Vol. 20, No. 3, pp. 709-740. 
Cochrane, John. 2007. Efficient Markets Today. Talk at the Conference on Chicago Economics in November 2007.

Coles, J., and U. Loewenstein. 1988. Equilibrium Pricing and Portfolio Composition in the Presence of Uncertain Parameters. Journal of Financial Economics, 22, 279-303.

Coles, J., U. Loewenstein, and J. Suay. 1995. On Equilibrium Pricing Under Parameter Uncertainty. Journal of Financial and Quantitative Analysis, 30, 347-376.

Dahlquist, M., and Robertsson, G. 2001. Direct Foreign Ownership, Institutional Investors, and Firm Characteristics. Journal of Financial Economics. 59, 413-40.

David, A. 2008. Heterogeneous beliefs, speculation, and the equity premium, Journal of Finance, vol. 63, no. 1 , pp. $41-83$.

Del Guercio, D., 1996. The Distorting Effect of the Prudent-Man Laws on Institutional Equity Investment. Journal of Financial Economics. 40, 31-62.

DellaVigna, S. and J. M. Pollet. 2009. Investor inattention and Friday earnings announcements. The Journal of Finance, 64(2):709-749.

Dittmar, A., and A. Thakor. 2007. Why Do Firms Issue Equity? Journal of Finance 62-1, 1-54.

Dzielinski, M., and H. Hasseltoft. 2014. Why Do Investors Disagree? The Role of a Dispersed News Flow. Working Paper.

English, William B., Skander J. Van den Heuvel, and Egon Zakrajsek. 2012. Interest Rate Risk and Bank Equity Valuations. Finance and Economics Discussion Series Divisions of Research and Statistics and Monetary Affairs Federal Reserve Board, Washington, D.C.

Ferson, W., and J. Lin. 2014. Alpha and Performance Measurement: The Effects of Investor Disagreement and Heterogeneity. Journal of Finance, 69: 1565-1596.

Flannery, Mark and C. James. 1984. Market Evidence on the Effective Maturity of Bank Assets and Liabilities Journal of Money, Credit and Banking, pp. 435-445.

Flannery, Mark J., Kwan, Simon H. and Nimalendran, M., 2004. Market evidence on the opaqueness of banking firms' assets. Journal of Financial Economics, vol. 71(3), pages 419-460.

Flannery, Mark J., Kwan, Simon H., and Nimalendran, Mahendrarajah. 2013. The 2007-2009 Financial crisis and bank opaqueness. Journal of Financial Intermediation, Vol. 22, 1, p. 55-84

Foster, F. D. and S. Viswanathan, 1996. Strategic trading when agents forecast the forecasts of others. Journal of Finance 51, 1437-1477. 
Gallant, A. R., P. E. Rossi, and G. Tauchen. 1992. Stock Prices and Volume. Review of Financial Studies 5, 199-242.

Garfinkel, J. A., and J. Sokobin. 2006. Volume, Opinion Divergence, and Returns: A Study of PostEarnings Announcement Drift. Journal of Accounting Research 44 (1): 85-112.

Garfinkel, J. A. 2009. Measuring Investors' Opinion Divergence. Journal of Accounting Research 47 (5): 1317-1348.

Gervais S. and T. Odean. 2001. Learning to be overconfident. Review of Financial Studies, 14(1):1-27.

Giliberto, M. 1985. Interest Rate Sensitivity in the Common Stocks of Financial Intermediaries: A Methodological Note. Journal of Financial and Quantitative Analysis, Volume 20, Issue 01, pp 123-126.

Harris, M. and A. Raviv. 1993. Differences of Opinion Make a Horse Race. Review of Financial Studies 6, 473-506.

Harrison, J. M., and D. M. Kreps. 1978. Speculative investor behaviour in a stock market with heterogeneous expectations. Quarterly Journal of Economics 92, 323-336.

He, H., and J. Wang. 1995. Differential Information and Dynamic Behavior of Stock Trading Volume. Review of Financial Studies, 8, 919-972.

Huang, S., and A. Thakor. 2013. Investor Heterogeneity, Investor-Management Disagreement and Share Repurchases. Review of Financial Studies, 26-10, 2453-2491.

Huberman, G. and T. Regev. 2001. Contagious speculation and a cure for cancer: A non-event that made stock prices soar. The Journal of Finance, 56(1):387-396.

Kandel, E. and N. Pearson. 1995. Differential Interpretation of Public Information and Trade in Speculative Markets. Journal of Political Economy, (103) 4 831-871.

Karpoff, J. 1987. The Relation between Price Changes and Trading Volume: A Survey. Journal of Financial and Quantitative Analysis 22, 109-126.

Karpoff, J., and R. Walkling. 1988. Short-Term Trading Around Ex-Dividend Days: Additional Evidence. Journal of Financial Economics, 21, 291-298.

Karpoff, J., and R. Walkling. 1990. Dividend Capture in NASDAQ Stocks, Journal of Financial Economics, 28, 39-65.

Kim, O., and R. Verrecchia. 1994. Liquidity and Volume around Earnings Announcements. Journal of Accounting and Economics 17: 41-67. 
Lakonishok ,J., and S. Smidt. 1986. Volume for Winners and Losers: Taxation and Other Motives for Stock Trading. Journal of Finance, 41, 951-974.

Lakonishok, J., and T. Vermaelen. 1986. Tax-Induced Trading Around Ex-Dividend Days. Journal of Financial Economics, 16, 287-319.

Landier, A., D. Sraer, and D. Thesmar. 2013. Banks' Exposure to Interest Rate Risk and the Transmission of Monetary Policy. Working Paper.

Lo, A. W. and J. Wang, 2000. Trading Volume: Definitions, Data Analysis, and Implications of Portfolio Theory. Review of Financial Studies, v13 (2, Summer), 257-300.

Lynch-Koski ,J. 1996. A Microstructure Analysis of Ex-Dividend Stock Price Behavior Before and After the 1984 and 1986 Tax Reform Acts, Journal of Business, 69, 313-338.

Merton, R. 1987. A Simple Model of Capital Market Equilibrium with Incomplete Information. Journal of Finance, 42, 483-510.

Michaely, R. 1991. Ex-Dividend Day Stock Price Behavior: The Case of the 1986 Tax Reform Act. Journal of Finance, 46, 845-860.

Michaely, R., and M. Murgia. 1995. The Effect of Tax Heterogeneity on Prices and Volume Around the Ex-Dividend Day: Evidence from the Milan Stock Exchange. Review of Financial Studies, 8, 369-399.

Michaely, R., and J. Vila. 1995. Investors' Heterogeneity, Prices and Volume Around the Ex-Dividend Day. Journal of Finance and Quantitative Analysis, 30 ,171-198.

Michaely, R., and J. Vila. 1996. Trading Volume with Private Valuation: Evidence from the Ex-Dividend Day. Review of Financial Studies, 9, 471-509.

Milgrom, P. and N. Stokey. 1982. Information, trade and common knowledge. Journal of Economic Theory 26 (1): 17-27.

Morgan, Donald P. 2002. Rating banks: Risk and uncertainty in an opaque industry. American Economic Review 92, 874-888.

Odean, Terrance. 1999. Do Investors Trade Too Much? American Economic Review, Vol. 89, 12791298.

Petersen, Mitchell A. 2009. Estimating Standard Errors in Finance Panel Data Sets: Comparing Approaches. Review of Financial Studies, 22 (1): 435-480.

Purnanandam, A. 2007. Interest rate derivatives at commercial banks: An empirical investigation. Journal of Monetary Economics 54 (6), pages 1769-1808. 
Roll, R. 1984. A Simple Implicit Measure of the Effective Bid-Ask Spread in an Efficient Market. The Journal of Finance, Vol. 39, No. 4, pp. 1127-1139.

Ruprecht, B., O. Entrop, T. Kick, and M. Wilkens. 2013. Market Timing, Maturity Mismatch, and Risk Management: Evidence from the Banking Industry. Working Paper.

Saunders, A. and M. M. Cornett. 2008. Financial Institutions Management: A Risk Management Approach. McGraw-Hill Higher Education; 6 edition.

Schrand, C. 1997. The Association between Stock-Price Interest Rate Sensitivity and Disclosures about Derivative Instruments. The Accounting Review, Vol. 72, No. 1, pp. 87-109.

Schultz, Paul, 2000, Stock Splits, Tick Size, and Sponsorship, Journal of Finance 55: 429-450.

Song, F.M. 1994. A Two-Factor ARCH Model for Deposit-Institution Stock Returns, Journal of Money, Credit and Banking, Vol. 26, No. 2, pp. 323-340.

Stickel, S. 1991. The Ex-Dividend Day Behavior of Nonconvertible Preferred Stock Returns and Trading Volume. Journal of Finance and Quantitative Analysis, 26, 45-61.

Tkac, P. 1999. A Trading Volume Benchmark: Theory and Evidence. The Journal of Financial and Quantitative Analysis, Vol. 34, No. 1, pp. 89-114.

Wang, J. 1994. A Model of Competitive Stock Trading Volume. Journal of Political Economy, 102, 127168.

Yin, W. 2010. An empirical research on China's stock market's volume-volatility relationship. World Economic Outlook 3, 66-79

Zhao, L. and Y. Wang, 2003. Hushen stock markets' volume, return and volatility correlations: evidence from empirical data analysis. Economic Science 2, 57-67. 